INTERNATIONAL JOURNAL OF INNOVATION IN ENTERPRISE SYSTEIM

Journal homepage: https://ijies.sie.telkomuniversity.ac.id e-ISSN: 2580-3050, DOI: https://doi.org/10.25124/ijies.v6i01.144

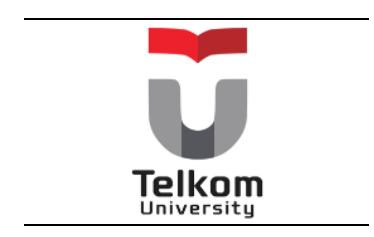

\title{
Analysis of Student Mentality with Rating Scale Mental Effort on Online Lecturing
}

Mira Rahayu $^{1}$, Dino Caesaron ${ }^{2 *}$, Celline Isabel Elvira Angkuw ${ }^{3}$, Helena Dinda Putri Naila ${ }^{4}$, Muhammad Khalid Asy-syafi' ${ }^{5}$, Muhammad Rifqi Fahmi Hidayat ${ }^{6}$

${ }^{1}$ School of Industrial and System Engineering

Telkom University, Bandung, Indonesia

mirarahayu@telkomuniversity.ac.id

${ }^{2}$ School of Industrial and System Engineering

Telkom University, Bandung, Indonesia

dinocaesaron@telkomuniversity.ac.id

${ }^{3}$ School of Industrial and System Engineering

Telkom University, Bandung, Indonesia

cellinea@student.telkomuniversity.ac.id

${ }^{4}$ School of Industrial and System Engineering

Telkom University, Bandung, Indonesia

helendnda@student.telkomuniversity.ac.id

${ }^{5}$ School of Industrial and System Engineering

Telkom University, Bandung, Indonesia

khalidsyafii@student.telkomuniversity.ac.id

${ }^{6}$ School of Industrial and System Engineering

Telkom University, Bandung, Indonesia

muhammadrifqifh@student.telkomuniversity.ac.id

*dinocaesaron@telkomuniversity.ac.id

\section{ARTICLE INFO}

Article history:

Received 24 July 2021

Accepted 01 January 2022

Published 31 January 2022

Keywords:

Online Lectures; Mental

Workload; RSME;

Students; Learning
ABSTRACT

Online lectures are distance learning carried out by all students and teachers who are in separate locations and involve multiple platforms in the implementation of online lectures. The problems experienced by students related to online lectures such as difficulties in using technology, and understanding the material so that it triggers a high mental workload from each student. This study aims to analyze the mental workload of industrial engineering students at Telkom University, Bandung. This study uses the Rating Scale Mental Effort (RSME) method to determine the mental workload related to the use of technology in online lectures. In the results of measuring mental workload, using a questionnaire distributed to students with 48 respondents. Based on the results obtained, the indicator that received the highest average RSME value reached 83.75, on the work anxiety indicator. Therefore, it is necessary to improve online learning and further research.

This is an open-access article under the CC BY-NC-SA license. 


\section{INTRODUCTION}

The world is being rocked by an outbreak of the coronavirus disease which is often called Covid-19, at the end of 2019 this outbreak began to be found in Wuhan, China. All countries in the world are affected by this outbreak, including Indonesia. The spread of this epidemic is so fast that the number of cases every day is always increasing. Based on this, the government implemented policies in the form of implementing health protocols, including maintaining distance, washing hands and wearing masks. This of course causes everyone to reduce activities outside the home. Various activities such as work and study must be done at home. This is done to avoid physical contact between students and educators. Regarding this policy, the Ministry of Education and Culture has issued a circular regarding the implementation of online learning as an effort to prevent the spread of Covid-19 since March 2020 [1]. With this circular, all learning activities in higher education have turned into online learning. Learning online is not an easy thing for students, it is necessary to adapt quickly to technology so that this becomes a new problem. In carrying out these online lectures, there are various problems experienced by students such as difficulties in using technology, difficulties in understanding lecture material, difficulties in carrying out assigned tasks, and also problems related to the mental workload experienced by each student given the number of courses, assignments and activities others have to deal with. The change in the lecture system from face-to-face to online lectures became less efficient and made students stressed, and worried about the lack of knowledge gained. Stress and worry are included in the mental workload, it is a set of factors that affect the mental processing of information, providing decision making and individual reactions in the workplace.[13] Mental workloads can be analyzed using several methods, for this research we use Rating Scale Mental Effort (RSME) because this method only focused on one dimension, namely mental effort [6].

Several studies explain that, in some states, online learning students fare much worse in terms of persistence, but this only happens in certain types of learning, the online learning process is also difficult because the level of ability of each student can't be observed directly [16]. Thus, failure to consider various things could mean that students can underestimate the negative things and the impact of online learning. This happens because students are used to face-toface learning, while distance learning is very rarely done, maybe some have never done this learning system. This change in learning patterns provides so many separate problems for students, indirectly students are required to study independently and of course involve mental or psychological activities of each student [25]. This is a demand for students to adapt technology with the aim of supporting online learning. This is a problem that is experienced by many students, some of them do not have complete facilities as well as economic problems for everyone. This is certainly a mental pressure that requires every student to have complete facilities in order to achieve effective and efficient learning. This is one of the causes of the increased mental workload, that is the imbalance between capacity and demands of workload because the workload is greater than the available resources such as facility [19].

Online learning begins in early March in 2020 when the even semester of lectures is underway. Adaptation and use of technology related to online learning should be done by students and lectures [2]. Online learning provides opportunities for students and lecturers to be able to study wherever and whenever they are. The online learning process is a learning whose success will be greatly influenced by the ability of teachers to use technology and students who explore various things using available technology. The online learning process utilizes various technological advances such as video, multimedia, virtual classes, email, online video streaming and many more. This process is also carried out in two directions in which the teacher can provide assignments or materials through online media then students actively and independently work on the assigned tasks. Two-way online learning is carried out when teachers and students are in a virtual room provided so that they can interact with each other. This of course becomes younger with the availability of online platforms. Online platforms are often used by students and lecturers to communicate, and as a place to provide creative materials to be accessed [3]. The use of online platforms requires the readiness of lecturers and students to have the ability and skills to use media to support online lectures. Various online platforms that can be used to support online learning activities include Google Classroom, LMS Telkom University, Edmodo, and many more.

Based on the platforms previously mentioned, Telkom University students use several platforms to help facilitate the online learning process such as: LMS (Learning Management System), Google Classroom, Google Meet, Zoom, and other platforms. This platform can be used according to user requirements. Like the LMS that students use to upload assignments, access lecture materials, take quizzes and exams. Meanwhile, Google meet and Zoom are used for face-toface online meetings so that lecturers can interact with students. We took some data from several Telkom University students with the following data. 


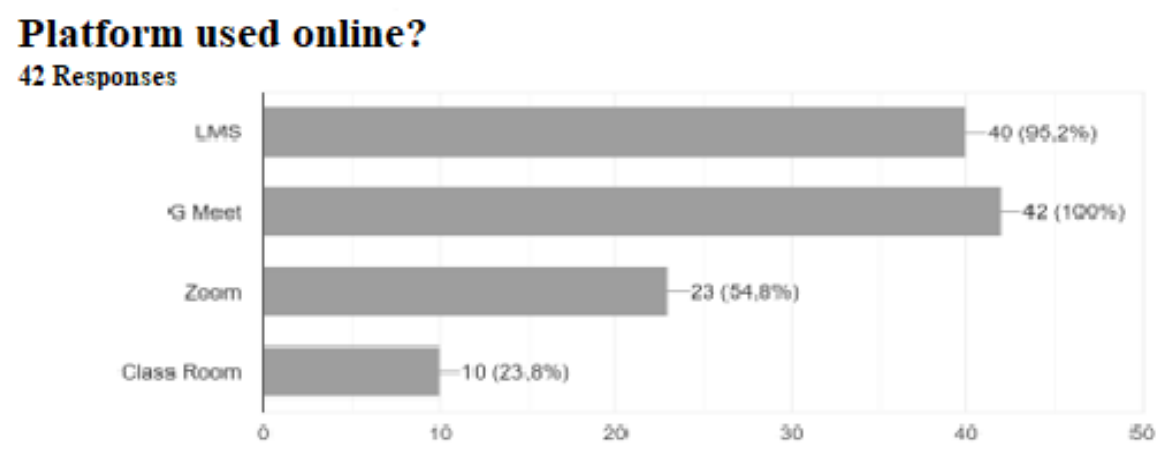

Figure 1 - Platform graphics used by Telkom University students

Figure 1 shows what platforms are often used in online learning for Telkom University students to help smooth the learning process. From the results obtained it is known that as many as 42 respondents who answered the questions given. As many as $100 \%$ of respondents chose Google Meet as a platform for interaction between students and lecturers during the learning and teaching process. As many as $95.2 \%$ of students use the LMS (Learning Management System) platform in accessing various assignments, quizzes, learning materials and exams. As many as $54.8 \%$ of students choose the video zoom application in the interaction of the lecture learning process, but this platform is not used too often because it is paid so that it prioritizes the google meet video platform because it is easy to access. As many as $23.8 \%$ of students choose Google class rooms, the use of the class room platform is rarely used because in learning Telkom University has provided an LMS (Learning Management System) to make it easier for students to access various things needed. The platforms that are used over time of course the number will continue to grow, as for the possibility that if there are more users there will be a down server on the platform itself. This problem often occurs with students, which will make it difficult for all students to access the platform, even maintenance often occurs which sometimes takes quite a long time to make it difficult for students to access assignments or materials, as well as difficulties in sending assignments on the platform. This will be one of the factors which will increase the mental workload of the students themselves because of the stress of various things that have been prepared but have been missed. This is related to the growth of technology and computerization that makes people to process more information that they receive cognitively so it can increase the mental workload.[19]

We also measured the level of mental burden experienced by students on a scale of 0 to 10 , where 0 shows feeling unencumbered and 10 shows feelings of burden, where the data are as follows:

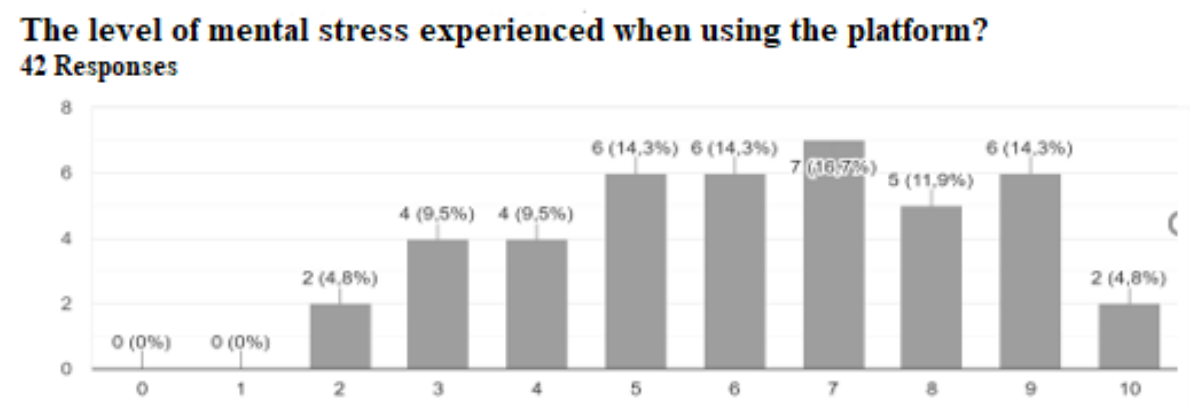

Figure 2 - Level of mental burden experienced by Telkom University students

Based on Figure 2, there is a scale of 0 to 10 with the aim of measuring the mental stress level experienced by students when using the platform, as many as 42 respondents chose each scale. It can be seen that as many as $4.8 \%$ of respondents who filled out on a scale of $2,9.5 \%$ of respondents who filled out on a scale of $3,9.5 \%$ of respondents who filled out on a scale of 4 , as many as $14.3 \%$ of respondents who filled out on a scale of 5, as many as $14.3 \%$ of respondents who filled in scale 6 , there are $16.7 \%$ of respondents who fill in scale 7 , as many as $11.9 \%$ who fill in scale 8 , there are $14.3 \%$ of respondents who choose scale 9 and there are $4.8 \%$ of respondents who choose scale 10 . This shows that the first position is on a scale of 7 , then on a scale of 9 , scale 6 , and scale 5 . This can prove that the amount of stress experienced by students when using online platforms. This is a new transformation during the pandemic, because previously students were not used to or not too often in using online platforms, because they always did face-to-face learning. In addition, on 
the platform there are various features that may be new and difficult to understand in using them, therefore adjustments are needed. This is what causes the mental stress experiences of students when using the platform is quite high.

We also measure the average time of study time conducted by students every day with the following data:

\section{Time to use the platform in one day? 42 Responses}
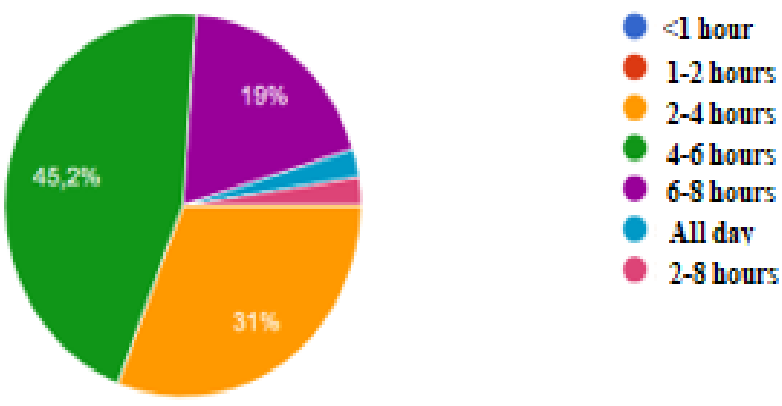

Figure 3 - Diagram Showing Time in Using Online Platform

Based on Figure 3, as many as 42 respondents gave their responses to how long they use the platform in one day. As many as $45.2 \%$ of respondents chose $4-8$ hours in one day, $31 \%$ of respondents chose $2-4$ hours of platform use in one day, $19 \%$ of respondents chose 6-8 hours of platform use in a day, $2.4 \%$ of respondents chose $2-8$ hours of using the platform in one day, and $2.4 \%$ chose $2-8$ hours of using the platform all day. Based on the results obtained, it shows the length of activities carried out by students in using the online platform. Most students do 4-6 hours of learning every day, of course it's a normal time but at this time online not a few lecturers give more assignments, even students need time outside of learning to be able to understand the material and sometimes coupled with activities outside the lecture such as community, organization, and others. At the same time, students should be able to divide their time.

Telkom University provides online platforms such as LMS (Learning Management System) which is a virtual facility specifically for students to be able to access various lecture materials, assignments, quizzes, google meet rooms and zoom. The various activities previously mentioned require students to use online platforms because assignments have deadlines and must be monitored in order to avoid delays in sending assignments, as well as quizzes which are held every day by lecturers in each field of learning and students must take the quiz to test their understanding of given material. This is the main reason why students use online platforms for a long time, even a full day, so that the mental workload of students increases.

Therefore, this research aims to know the scale of mental workload experienced by students using RSME method, which will be described also a good solution to reduce the mental workload experienced, so that students can still follow this online learning activity without experiencing significant fatigue and minimize the occurrence of quality degradation from the student itself.

Goal:

1. To determine the mental workload of Telkom University students.

2. To assess the mental workload of Telkom University students during online learning.

3. To find out the effectiveness of using online learning platforms of Telkom University students.

Benefits:

1. Identify the size of the metal workload of Telkom University students.

2. Considering an effective platform for online learning for Telkom University students.

3. Optimizing the use of online learning platforms of Telkom University students.

\section{METHOD}

This research was conducted to solve problems related to the mentality of Telkom University students. The research methodology can be seen on Fig 4. In this research, the selected object was the effect of learning using online technology on the mentality of students of Telkom University. 
Mental workload is an indicator of the amount of mental attention or demands required to complete a job [4]. The object selection acted as a source of data in research to get a clearer picture concerning the effect of learning using online technology on the mentality of students. According to Munandar, there are two aspects that become the workload, namely [5]:

a. Workload as Physical demands. Certain working conditions can produce optimal work performance in addition to its impact on one's performance, physical conditions also have an impact on one's mental health. The physical condition of workers has an influence on the fatal condition and psychology of a person. In this case, health conditions must remain in good health while doing work, in addition to adequate rest also with the support of comfortable and adequate workplace facilities.

b. Workload as task demands often cause fatigue for students as a result of excessive work demands. Excessive workload and too little workload can affect a person's performance.

Based on the explanation from the previous sub-chapters, this research was focused on finding answers to the following problem formulation:

1. What are the factors affecting the mentality of students in online learning?

2. How does the use of online platforms for online learning affect the mentality of students?

3. What are the disadvantages of using online platforms in online learning?

In several studies, there are various measurements of subjective mental workload, namely the measurement of mental workload based on subjective perceptions of respondents/workers. Subjective measurement is a measurement based on the assessment and reporting by workers of the workload they get in carrying out a task. This type of measurement generally uses a rating scale. The following are some types of subjective measurement methods:

a. Subjective Workload Assessment Technique (SWAT), the SWAT method is a multidimensional scale. In the SWAT model, human work performance consists of three dimensions of workload measurement associated with performance, namely: Time load, mental effort, psychological stress [15].

b. NASA TLX, in NASA TLX there are 6 dimensions of workload size, namely mental demand, physical demand, temporal demand, performance, effort and frustration Level [13]. In this stage the subject is asked to choose between two SWAT dimensions, which according to the subject make a greater contribution to the workload they experience [24].

c. Modified Cooper Harper Scaling. This method is the method used to analyze the physical workload and mentality faced by workers who have to do various activities at work [14].

d. Mental workload measurement can be done in two ways, namely objective measurement can be done with several body parts, including heart rate, eye blinking and muscle tension. Measurement of mental workload subjectively is the most widely used measurement technique because it has a high level of validity and is direct compared to other measurements [23]. This study will use the Mental Effort Rating Scale (RSME) as a new alternative in measuring subjective mental workload. Performance criteria, namely the level of accuracy and reaction time will also be used to validate the measurement results. 


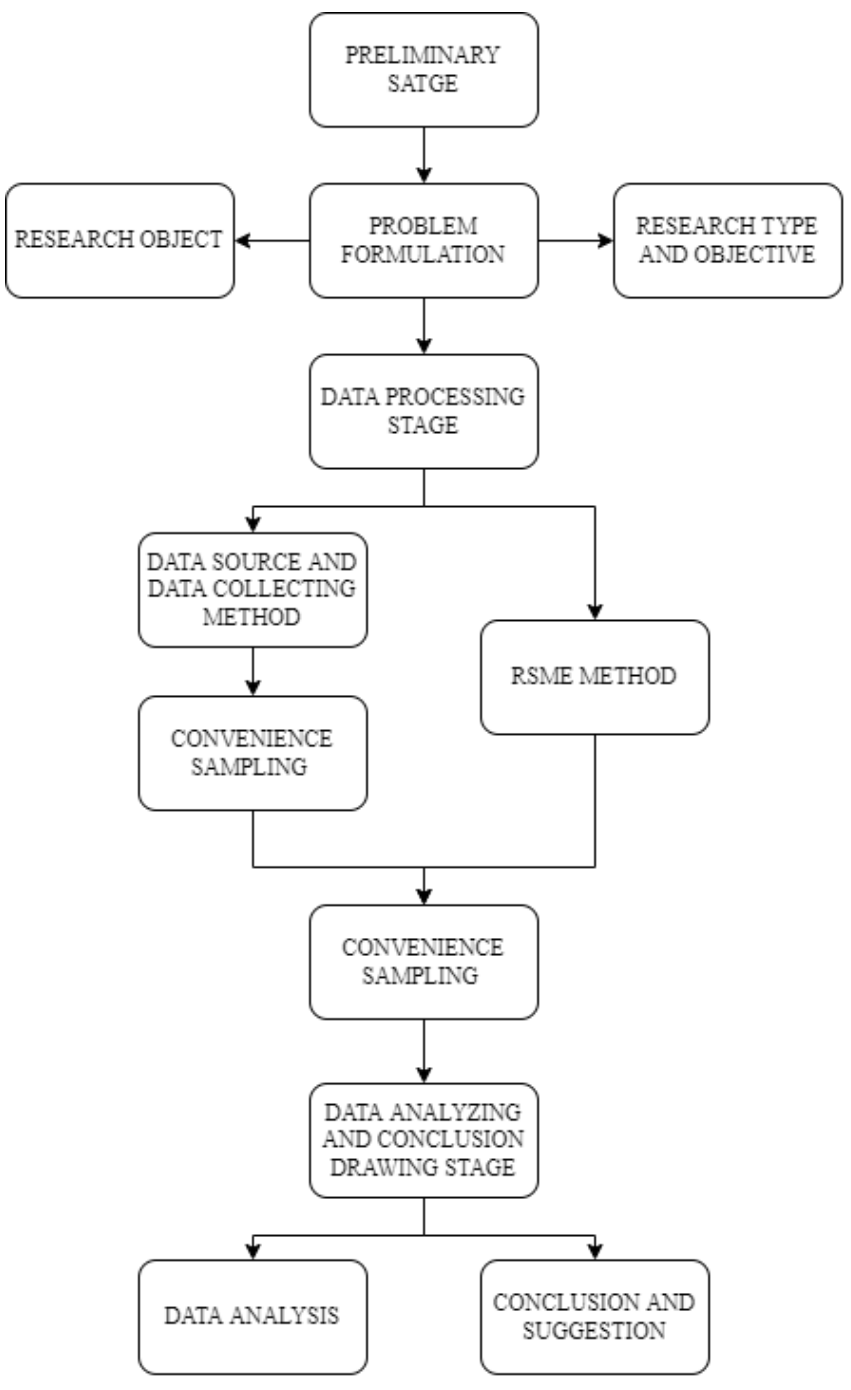

Figure 4 - Methodology Research

This research belonged to evaluation research and case study research. An evaluation research aims to re-check the process of a system, and this research also finds results in the form of advantages and disadvantages in the implementation of said process. Therefore, in the future, system improvements can be applied to make it better. A case study research is extracting in-depth information through existing problems in the vicinity and processing data or information concerning the problems, to provide support in finding solutions. The purpose of this research was to observe and analyze the problems that occurred, in this case the effect of learning using online technology on the mentality of students.

A data source is all information obtained through data. In this study, the respondents were Telkom University students. Data collection methods use quantitative methods in the form of questionnaires. The questionnaire will be distributed by researchers through google form that will be filled out by respondents. Data collection is done scientifically and systematically. The authors conducted the survey by distributing questionnaires as research instruments. This study uses addental sampling methods (convenience sampling). Convenience sampling is a technique of taking respondents as a sample by chance, namely anyone who coincidentally meets with researchers and is used as a sample (Sugiyono, 2009) [18]. Thus, this method becomes an effective and efficient way to collect data that will be measured numerically.

The RSME includes subjective workloads with one-dimensional scaling, The RSME is an assessment method focused on one scale, from 0-150, regarding mental effort [6]. In some studies, the RSME method uses a questionnaire that will be distributed to respondents. In this questionnaire, the respondent will give a value rating on the six demand factors physically. The questionnaire contains respondent's personal data, and various questions related to mental workload. The next stage in this method is the giving stage the weight by which the respondents will give a rating to the six indicators contained in the method RSME with a score of 0 to 150 depending on mental load that is felt.

Based on several studies, RSME only measures the mental effort experienced by a person, which can be completed in less than one minute. There are various scales using the RSME method, this scale is certainly a benefit and a benchmark 
in assessing the diagnostic. In a sense, all aspects of the workload can determine a certain limit and what factors can lead to mental workload. In previous research, it was stated that the rating scale was sensitive to changes in a person's mental workload in various conditions [17]. The measurement using the RSME method involves a scale consisting of a vertical line with 150 points with an interval of $1 \mathrm{~cm}$ for each point. In accordance with data processing using the RSME method, the final score of mental workload was obtained according to the rating chosen by the respondents on the RSME questionnaire. Respondents will choose a rating from a scale of 0-150 with 9 categories [21].

In the RSME method, the results of the questionnaires that have been filled out by respondents do not require data processing. The higher the scale, the higher the mental workload effort [11]. The data generated from the questionnaire can be directly analyzed according to the scale given by the respondent. The respondents only needed to measure how much mental effort is required in performing their jobs. In data processing using the RSME method, the final score is the scale chosen by the respondent by looking for the average of the mental workload values [12] Indicators of mental work effort in this questionnaire include workload, work difficulties, job performance or satisfaction, work mental effort, work anxiety and work fatigue [6].In this research, students of Telkom University filled out a questionnaire about the mental workload experienced by them. The indicators of the RSME Method consist of: (1) Workload (WL), (2) Work Difficulty (JD), (3) Work Performance (P), (4) Mental Effort (WME), (5) Work Anxiety (WA), and Work Fatigue (F). The results of the RSME scale assessment can then be categorized into the following groups [5]:

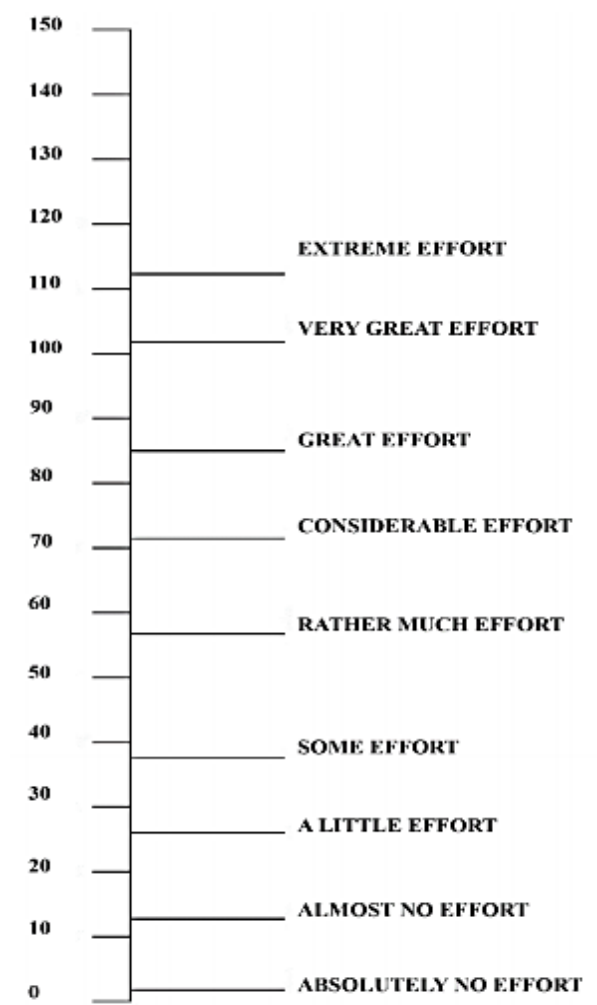

Figure 5 - The Indicators of the RSME Method

\section{RESULT AND DISCUSSION}

The next stage is the collection of research data involving respondents, namely Telkom University Students, especially the Department of Industrial Engineering class of 2018 and 2019. The data used includes age and gender. Furthermore, there are 6 question indicators filled using RSME scale, namely:

a. How hard is the job you do during online studying? (Workload)

b. How big is the level of difficulty in understanding lecture material online? (Job Difficulty)

c. How do you rate your performance online? (Performance / Job Satisfaction)

d. In your opinion, how much mental work do you put into online lectures? (Work Mental Effort)

e. How much anxiety did you feel in online college? (Work anxiety)

f. How much fatigue did you feel when you were studying online? (Fatigue)

The next step is data processing to view and evaluate the mental workload assessment of respondents using the RSME method. Result of data on gender and age of respondents: 
Table 1 - Percentage of Gender and Age of Respondents

\begin{tabular}{|c|c|c|c|}
\hline \multicolumn{2}{|c|}{ Respondents } & \multirow{2}{*}{$\begin{array}{c}\text { Total } \\
18\end{array}$} & \multirow{2}{*}{$\begin{array}{c}\% \\
37.50 \%\end{array}$} \\
\hline Gender & Male & & \\
\hline & Female & 30 & $62.50 \%$ \\
\hline \multirow[t]{2}{*}{ Age } & 19 & 35 & $72.90 \%$ \\
\hline & 20 & 13 & $27.08 \%$ \\
\hline
\end{tabular}

Based on Table 1, the total respondents were 48 students including Telkom University students class of 2019 and some of the 2018 batch students consisting of 18 male students and 30 female students, with 35 students aged 19 years old and 13 students aged 20 years old.

The following are the results of RSME data collection for each variable are shown in Table 2:

Table 2 - RSME Value Calculation

\begin{tabular}{|c|c|c|c|c|c|c|}
\hline Respondents & $\mathbf{W L}$ & JD & $\mathbf{P}$ & WME & WA & WF \\
\hline $\mathrm{R} 1$ & 70 & 60 & 60 & 70 & 70 & 70 \\
\hline $\mathrm{R} 2$ & 20 & 30 & 10 & 20 & 30 & 30 \\
\hline R3 & 70 & 60 & 70 & 80 & 60 & 80 \\
\hline $\mathrm{R} 4$ & 110 & 100 & 60 & 130 & 140 & 120 \\
\hline R5 & 70 & 80 & 80 & 90 & 70 & 70 \\
\hline R6 & 20 & 20 & 30 & 20 & 30 & 10 \\
\hline $\mathrm{R} 7$ & 100 & 100 & 100 & 100 & 120 & 120 \\
\hline $\mathrm{R} 8$ & 50 & 50 & 50 & 50 & 90 & 50 \\
\hline R9 & 30 & 30 & 20 & 30 & 30 & 30 \\
\hline $\mathrm{R} 10$ & 80 & 110 & 80 & 120 & 130 & 150 \\
\hline R11 & 100 & 90 & 40 & 100 & 110 & 50 \\
\hline $\mathrm{R} 12$ & 30 & 30 & 20 & 30 & 30 & 30 \\
\hline R13 & 20 & 20 & 20 & 20 & 20 & 20 \\
\hline $\mathrm{R} 14$ & 20 & 20 & 10 & 30 & 30 & 30 \\
\hline $\mathrm{R} 15$ & 100 & 150 & 100 & 100 & 150 & 150 \\
\hline R16 & 130 & 100 & 80 & 150 & 150 & 150 \\
\hline $\mathrm{R} 17$ & 40 & 90 & 40 & 40 & 20 & 40 \\
\hline $\mathrm{R} 18$ & 100 & 70 & 100 & 100 & 130 & 140 \\
\hline R19 & 60 & 130 & 80 & 150 & 130 & 150 \\
\hline R20 & 110 & 100 & 40 & 110 & 110 & 150 \\
\hline R21 & 60 & 70 & 60 & 80 & 90 & 80 \\
\hline R22 & 80 & 60 & 50 & 80 & 80 & 90 \\
\hline $\mathrm{R} 23$ & 70 & 80 & 50 & 70 & 90 & 90 \\
\hline $\mathrm{R} 24$ & 80 & 120 & 50 & 90 & 120 & 140 \\
\hline $\mathrm{R} 25$ & 100 & 110 & 100 & 90 & 130 & 50 \\
\hline R26 & 30 & 20 & 20 & 30 & 30 & 30 \\
\hline $\mathrm{R} 27$ & 60 & 50 & 70 & 40 & 20 & 50 \\
\hline R28 & 120 & 100 & 110 & 130 & 130 & 140 \\
\hline R29 & 40 & 80 & 60 & 70 & 60 & 70 \\
\hline R30 & 70 & 100 & 70 & 150 & 150 & 50 \\
\hline
\end{tabular}




\begin{tabular}{ccccccc} 
R31 & 90 & 70 & 90 & 90 & 90 & 80 \\
R32 & 120 & 140 & 120 & 120 & 80 & 90 \\
R33 & 90 & 80 & 80 & 70 & 100 & 110 \\
R34 & 90 & 90 & 80 & 100 & 60 & 90 \\
R35 & 60 & 80 & 40 & 70 & 80 & 80 \\
R36 & 150 & 150 & 70 & 150 & 60 & 150 \\
R37 & 50 & 60 & 60 & 100 & 80 & 90 \\
R38 & 20 & 20 & 20 & 10 & 10 & 20 \\
R39 & 150 & 30 & 80 & 150 & 150 & 120 \\
R40 & 40 & 70 & 40 & 70 & 30 & 30 \\
R41 & 80 & 130 & 90 & 150 & 150 & 90 \\
R42 & 90 & 100 & 70 & 120 & 120 & 100 \\
R43 & 120 & 130 & 120 & 90 & 110 & 140 \\
R44 & 90 & 90 & 90 & 100 & 70 & 70 \\
R45 & 120 & 140 & 90 & 90 & 120 & 130 \\
R46 & 70 & 80 & 40 & 60 & 80 & 40 \\
R47 & 100 & 70 & 70 & 60 & 70 & 70 \\
R48 & 10 & 10 & 20 & 30 & 10 & 10 \\
Average & 74.583333 & 78.541667 & 62.5 & 83.125 & 83.75 & 82.083333 \\
Min & 10 & 10 & 10 & 10 & 10 & 10 \\
Max & 150 & 150 & 120 & 150 & 150 & 150 \\
Standard Deviation & 36.082549 & 37.980375 & 29.571407 & 40.431516 & 43.741261 & 44.480851 \\
\hline
\end{tabular}

The following is a graph of the average RSME results for each variable:

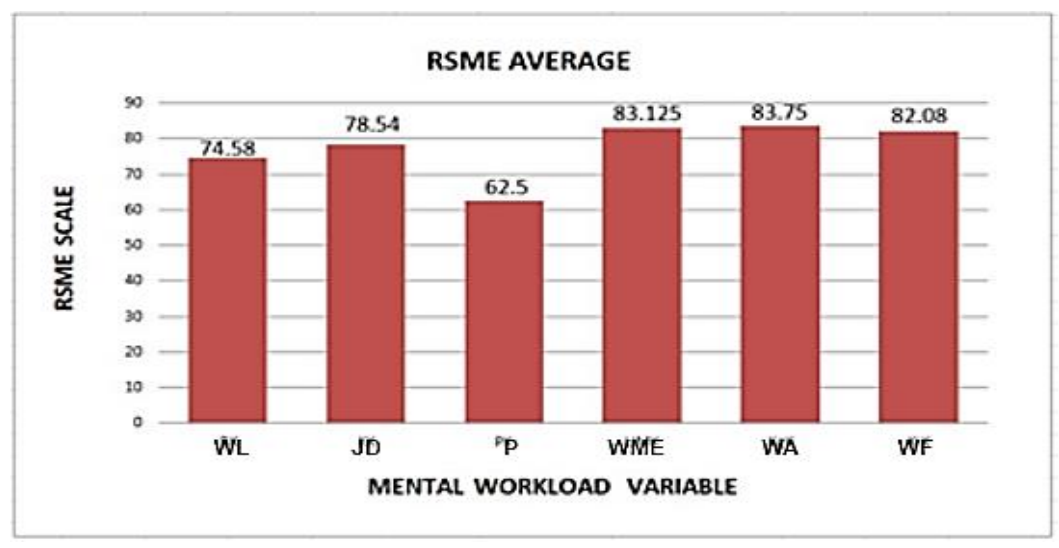

Figure 6 - Graph of Average RSME

Workload indicators are seen from a person's capacity or ability to face all of job demands [7]. Based on the average results, it can be seen that the workload is on a scale of 74.58. Then, the second indicator is work difficulty, which is a condition in which workers feel that there is a lack of ease in doing work. Based on this graph, work fatigue is on a scale of 78.54. Then the next indicator is work performance which is a work result or outcome resulting from a particular job. In graph 4.4 work performance shows a scale of 62.5 . Next is the mental work effort, namely the amount of attention or a mental demand to complete a job. In the graph, the average mental work effort is 83.12. Then there is work anxiety in which a worker feels uneasy and excessive worry. In the graph, work anxiety is in the highest position with the average value reaching 83.75. And the last one is work fatigue, where workers use their strength excessively so that in this graph the average work fatigue is 82.08 . Based on Table 2, the recapitulation of the overall workload value and the RSME 
graph above, it can be seen that the average work anxiety (WA) is the highest value of all indicators, then the second highest position is mental work effort (MWE), then the third is the work fatigue indicator (KIK), then the workload indicator (WL) and the last is work performance $(\mathrm{P})$.

Based on the results and our analysis of each Mental Effort Rating Scale indicator. In the workload indicator (WL), the average RSME value produced is 74.58. This shows that the mental workload experienced by students is quite high, related to how heavy the work is done during online lectures, this number shows the amount of work given to students. The number of course assignments, and various quizzes every week so that the mental workload increases [9]. This is because students are required to complete various assignments and quizzes within the same time span. This method must be improved by adjusting the assignments and the capacity of students' abilities to work on such a dense task in a short time span.

In the Work Difficulty (JD) indicator, the implementation of online learning is judged by the level of difficulty in understanding lecture material when online, showing an average RSME value of 78.54. This figure is more than the average value of the workload indicator. Everyone certainly has different ways and abilities in understanding the material, some are relaxed and some prefer to be serious in learning. Therefore, students need a strong and stable connection to stay focused on learning and not be distracted by the activities of the surrounding environment, either in the neighborhood or in the virtual world environment [8]. In addition, the ability to understand the material must be trained continuously so that it is not difficult to do assignments, quizzes and various other lectures.

The work performance indicator (P) shows the average RSME value of 62.5. Self-performance in conducting online learning is quite low than the average value of other indicators. Based on the average results, student satisfaction in online learning is still classified as moderate, meaning that students are not quite satisfied with work performance. This is due to a lack of focus in doing a given task due to self-efficacy which has difficulty understanding the task, so that the resulting score is unsatisfactory [20] as well as at the time of the exam many feel difficulties related to exam questions due to material that students have not understood so that satisfaction from work performance is still not maximal.

In the work mental effort (WME) indicator, the average RSME value produced is 83.125 , this number is considered to be higher than the previous indicator. Every job requires muscle strength or thinking so that is a burden on the perpetrator [22]. The amount of mental effort spent during online lectures is because students have to adapt well to new learning conditions, in this case technology and the way each individual learns, plus the many demands of students who have to work under pressure and are faced with it. With various internal responsibilities. As well as external. This is also due to environmental conditions, many students complain of experiencing distraction both from people who are at home from each student, as a result they are more lazy and lack motivation in learning besides that, students are in a comfortable place, namely at home it can cause sleepiness and force yourself to understand the material given, in the end with the many distractions that occur it can trigger a great mental effort from each student to fulfill the competence of graduates in each lectures.

The work anxiety indicator (WA) shows an average RSME value of 83.75. This figure is the highest average value of all indicators. Judging from the size of the average results show that students' anxiety in doing online learning is quite large. This is because students want to understand lecture material that is repetitive, in the sense that they can play learning videos anytime and anywhere [9], it could also be due to the limited facilities of each student so that the learning process does not go well. For example, some students do not have facilities such as $\mathrm{Wi}-\mathrm{Fi}$, so they require students to buy quotas, this is certainly a limitation because there are some whose parents may be less well off in terms of economy so it is difficult to complete the facilities to assist in the learning process. In the end, some of them missed the lesson, and did not understand the material being taught.

In the work fatigue indicator (WF) the average value of RSME is 82.08. Based on these results, the fatigue felt by students when studying online was so great. This is because students have to be in front of cellphone and laptop screens for hours and even a full day with various assignments and lecture demands that must be done [10]. This is very draining physically and psychologically. In online lectures, many students complain because of the stress of the demands of lectures. However, besides that they also continue to work on and complete the tasks and responsibilities given. Therefore, it is very necessary to have good time management in order to achieve the objectives of the lecture.

Based on the average results of the six indicators, the value obtained is included in the category of a fairly high mental workload. These results refer to the current situation during the COVID-19 pandemic which directly requires students to be able to adapt to online learning conditions with the use of increasingly developing technology, workload as physical demands. Certain working conditions can produce optimal work performance in addition to its impact on student performance. Physical conditions also have an impact on a student's mental health. Physical conditions have an influence on a person's fatal condition and psychology. In this case, that the health condition of students must remain in good health when conducting lecture activities during the pandemic, in addition to adequate rest also with the support of comfortable and adequate workplace facilities, many students do not have complete facilities personally so that indirectly demands them in adjusting the situation. The most influential factor is the workload as the task demands. Tasks that are so many and piled up in the close range of deadlines often cause fatigue for students due to excessive workloads. These things are 
the main factors in increasing the mental and physical paper load. Based on the results of the RSME Method, it is of concern to further develop effective and efficient online learning methods to increase willingness to learn, and enthusiasm in adapting various technologies used in online learning, with the aim of reducing the mental workload of students.

\section{CONCLUSION}

During this pandemic period is certainly very influential for students in doing learning online, starting from various uses of unstable platforms, and needing extra understanding. From this study, the indicator that shows the average result of students' mental workload is the largest for online lectures seen from the indicator work anxiety (WA) shows an average RSME value of 83.75 this is because students want to understand lecture material that is repetitive, and lack of facilities for each student such as network constraints which result in hampered learning processes. In the second order there is an indicator of mental work effort (WME) with an average RSME value of 83.125, the third indicator of work fatigue (F) with an average RSME value of 82.08, the fourth indicator average value of 82.08 workload (WL) with an. The average RSME value produced is 74.58, the five indicators of Work Difficulty (JD) in the implementation of online learning are judged by the level of difficulty in understanding lecture material when online shows an average RSME value of 78.54 and the sixth Work Performance indicator $(\mathrm{P})$ shows a value the average RSME is 62.5. These results indicate that there is a need for improvements and adjustments to online learning in terms of technology and the way each student learns. Therefore, our suggestions for the mental workload problem are to make daily plans so that time is more directed and timely, increase knowledge in applying the technology used, repeat material that has been taught during online lectures, and fill free time with activities that entertain yourself so that there is no greater workload. Based on the results obtained, RSME needs to be improved by combining it with other methods to make it more holistic, so it requires future research and the shortcomings in this study are in the form of statistical tests and to strengthen the research carried out further research is needed.

\section{Disclaimer}

The authors whose names are written certify that they have no conflict of interest.

\section{REFERENCES}

[1] Kemendikbud. SE Mendikbud: Pembelajaran secara Daring dan Bekerja dari Rumah untuk Mencegah Penyebaran Covid-19 melalui https://www.kemdikbud.go.id/main/blog/2020/03,2020.

[2] Astuti, R. L. Pengaruh Motivasi dan Beban Kerja Mental Terhadap Kinerja Perawat Pada Rumah Sakit Umum Mitra Medika Medan, 2018. Jurnal Ilman.

[3] Dewi, S. Platform Online Dalam Pendidikan Pada Masa Pandemi Covid-19, 2020. Jurnal Of Education Graduate School Of Universitas Negeri Malang.

[4] Fatin Saffanah Didin, I. M. Analisis Beban Kerja Mental Mahasiswa Saat Perkuliahan Online Synchronous Menggunakan Metode Rating Scale Mental Effort, 2020.

[5] Hancock, P. a. Human Mental Workload. North Holland: Elsevier Science Publisher,1998.

[6] Samuel H. P, M. M. Analisis Beban Kerja Mental Divisi HR \& GA PT. Pertamina Trans Kontinental dengan Metode Rating Scale Mental Effort (RSME), 2019.

[7] T., Y. E. Kesehatan Mental Mahasiswa Jadi Isu Utama Global, 2020. Kompas.com.

[8] Funsu, A. Pengaruh Pembelajaran Daring terhadap Stres Akademik Mahasiswa Selama Pandemi Covid-19, 2020. Jurnal Psikologi.

[9] Indah, W. Peranan Guru Dalam Pembelajaran Daring Pada Masa Pandemi Covid-19. Indonesian Journal of Teacher Education, 2020, pp. 159160.

[10] Fatin, S. D. "Analisis Beban Kerja Mental Mahasiswa saat Perkuliahan Online Synchronous dan Asynchronous Menggunakan Metode Rating Scale Mental Effort”, 2020. Jurnal Optimasi Sistem Industri, pp. 50-51.

[11] Helmi, D. S. “Analisis Beban Kerja Menggunakan Metode Rating Scale Mental Effort (RSME) dan Modified Cooper Harper (MCH) di PT. BANK X”, 2021. Jurnal IKRA-ITH TEKNOLOGI, pp. 11-10.

[12] Aji Pragoyo. Evaluasi Beban Kerja Mental Pengatur Perjalanan Kereta Api (PPKA) Dengan Menggunakan Metode NASA-TLX dan RSME, 2016, pp. 27-28.

[13] Ghanbary, S. A. Evaluation of Rating Scale Mental Effort (RSME) effectiveness for mental workload assessment in nurses, 2016, pp. 4-5.

[14] Shania, F. Aprilia, T. Analisis Beban Kerja Mental Pada Mahasiswa Terhadap Perkuliahan Offline dan Online Menggunakan Metode Modified Cooper Harper Scale, 2020, pp. 21-22.

[15] Muslimah. "Evaluasi Beban Kerja Mental Dengan Subjective Workload Assessment Technique (SWAT) Di PT. Air Mancur", 2014. Publik.si Ilmiah Universitas Muhammadiyah Surakarta, pp. 161-162.

[16] Ari, w. Addie, J. Dick, D. “Adaptation of the Rating Scale Mental Effort (RSME) for use in Indonesia”, 2013. International Journal of Industrial Ergonomics, pp. 71-73.

[17] Di Xu, Shanna, S. J. The impact of online learning on students' course outcomes: Evidence from a large community and technical college system, 2013, pp. 47-48.

[18] Meidatuzzahra, Diah. Penerapan Accidental Sampling Untuk Mengetahui Prevalensi Akseptor Kontrasepsi Suntikan Terhadap Siklus Menstruasi, 2019.

[19] Made, N., \& Wulanyani, S. Tantangan Dalam Mengungkap Beban Kerja Mental, 2015. 80-89.

[20] Anggraini ST., MM., MT,dkk. Analisis Beban Mental Mahasiswa Fakultas Teknik Ums Saa Dilaksanakan Pembelajaran Daring Selama Pandemi Dengan Metode Rating Scale Mental Effort (RSME), 2021, pp. 16-17. 
[21] Ayu Tri Rahayu, dkk. Analisis Beban Kerja Mental Menggunakan Metode National Aeronautics and Space Administration Task Load Index (NASA-TLX) dan Rating Scale Mental Effort (RSME), 2021. Prosiding SNAST.F-186

[22] Helmi D.S, Diah p. Analisis Beban Kerja Menggunakan Metode Rating Scale Mental Effort (RSME) dan Modified Cooper Harper (MCH) Di PT. BANK X, 2021, pp. 7-8.

[23] Risma Adelina. "Analisis Pengaruh Shift Kerja Terhadap Beban Kerja Mental dengan Metode Subjective Workload Assessment Technique (SWAT)", 2010. Jurnal Teknologi, pp. 55-56.

[24] Erni Krisnaningsih. "Pengukuran Beban Kerja Mental Operator Control Roommenggunakan Metode Subjective Workload Assesment Technique (SWAT) Di PY. Krakatau Steel (Persero) Tbk”, 2019. Jurnal Intent: Jurnal Industri Dan Teknologi Terpadu, pp. 35.36.

[25] Siti Sri Wulandari. "Pembelajaran Daring Sebagai Upaya Study From Home (SFH) Selama Pandemi Covid 19", 2020. Jurnal Pendidikan Administrasi Perkantoran (JPAP), pp. 498-4 